\title{
Estimating Water Use and Irrigation Requirements of Coffee in Hawaii
}

\author{
Marco V. Gutiérrez ${ }^{1}$ \\ Department of Horticulture, University of Hawaii at Manoa, Honolulu, Hawaii 96822 \\ Frederick C. Meinzer \\ Crop Science Department, Hawaiian Sugar Planters' Association, P.O. Box 1057, Aiea, Hawaii 96701
}

Additional index words. Coffea arabica, coffee, leaf area index, evapotranspiration, transpiration, stem heat balance technique

\begin{abstract}
Crop evapotranspiration (ET) was measured as evaporative heat flux from drip-irrigated coffee (Coffea arabica L. cv. Yellow Catuai) fields at different stages of canopy development using the Bowen ratio-energy balance technique. Irrigation requirements were determined by comparing the $\mathrm{ET}_{\mathrm{c}}$ values obtained against reference values $\left(\mathrm{ET}_{0}\right)$ derived

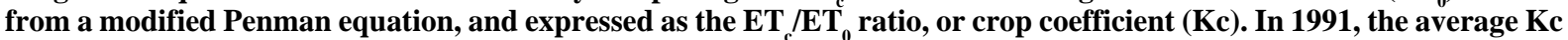
was 0.75 to 0.79 for fields containing 2- to 4-year-old plantings. This ratio was 0.58 for a field containing a 1-year-old

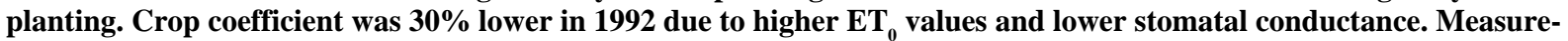
ments made between July and August and again between September and November 1991 suggested that Kc may vary seasonally. Crop transpiration (T), determined with the stem heat balance technique, comprised from $40 \%$ to $95 \%$ of ET as the leaf area index increased from 1.4 to 6.7. Behavior of $\mathrm{Kc}$ and $\mathrm{T}$ during a 25-day soil drying-reirrigation cycle indicated that the crop was able to maintain relatively high levels of gas-exchange activity during periods of severe water deficit.
\end{abstract}

The amount of acreage planted in coffee on Hawaii's sugar plantations has expanded dramatically during recent years. This return of coffee as a major commercial crop has been achieved through continued establishment of newly bearing acreage and improved care of the orchards. On the island of Kauai alone, over 1800 ha of coffee are being grown under drip irrigation (U.S. Dept. of Agriculture). Nevertheless, actual rates of water use by the crop have not been estimated.

Reasonably accurate water requirement estimates for coffee are crucial because too little water can substantially reduce growth without wilting or other visible signs of moisture stress (Meinzer et al., 1992). Reduced growth signifies that fewer nodes are present for flower formation and subsequent fruit production (Browning and Fisher, 1979; Cannell, 1971).

Water use by coffee and other crops is most usefully expressed as a ratio of crop evapotranspiration to the reference evapotranspiration $\left(\mathrm{ET}_{\mathrm{c}} / \mathrm{ET}_{0}\right)$, also known as the crop coefficient $(\mathrm{Kc})$. Estimates of $\mathrm{Kc}$ for coffee grown in other regions typically range from 0.7 to 0.8 (Blore 1966; Pereira, 1957; Wallis, 1963). However, these estimates have been obtained by indirect methods such as hydrological models or assessing changes in soil moisture. Pereira (1957), using a soil-water balance model reported that Kc for coffee growing in Kenya varied seasonally from 0.5 during the dry season to 0.8 during the wet season. Wallis (1963) and later Blore (1966) used soil moisture changes to estimate the irrigation requirements of coffee in Kenya and found $\mathrm{Kc}$ to be 0.6 and 0.7 for nonirrigated and irrigated coffee, respectively. Validation of these estimates under local conditions is desirable because of the relatively large variation in climate and agronomic practices among

Received for publication 1 June 1993. Accepted for publication 27 Oct. 1993. Research conducted at McBryde Sugar Co., Eleele, Kauai Island, Hawaii. Published as paper no. 794 in the journal series of the Experiment Station, HSPA. We gratefully acknowledge Peter Tausend and personnel at McBryde Sugar Co. for their cooperation in carrying out this study. The cost of publishing this paper was defrayed in part by the payment of page charges. Under postal regulations, this paper therefore must be hereby marked advertisement solely to indicate this fact. ${ }^{1}$ Present address: Universidad de Costa Rica, Estacion Experimental Fabio Baudrit, P.O. Box 183-4050, Alajuela, Costa Rica. coffee growing regions.

Our objective was to assess water use by drip-irrigated coffee growing in Hawaii using more direct approaches than those previously reported for coffee growing in other regions.

\section{Materials and Methods}

Experimental site and plant material. The study was conducted in commercial coffee fields at McBryde Sugar Co., Eleele, island of Kauai (lat. $21^{\circ} 54^{\prime} \mathrm{N}$, long. $154^{\circ} 33^{\prime} \mathrm{W}$, elev. $98 \mathrm{~m}$ ) from July to November in 1991 and from July to September in 1992. Precipitation patterns in Eleele are characterized by seasonal fluctuations in rainfall with a defined dry season from May to October. Large fields of Coffea arabica 'Yellow Catuai' from 37 to 74 ha were selected. The fields were planted in a hedgerow configuration oriented predominantly from east to west. Spacing at planting was $3.6 \mathrm{~m}$ between rows and $0.7 \mathrm{~m}$ between plants. 'Yellow Catuai' is a short and compact variety that forms dense hedgerows when cultivated at high density. Leaf area index (LAI) was 1.4, 5.3, 5.4, and 6.7 in 1991, and 3.4, 4.2, and 7.5 in 1992 in the seven fields selected. Crop age ranged from 1.2 to 5.3 years. Hedgerow dimensions increased approximately from $1.25 \times 1 \mathrm{~m}$ at LAI $=1.4$ to $3 \times 2.5 \mathrm{~m}$ at $\mathrm{LAI}=7.5$. Average leaf area per plant $(\mathrm{n}=8$ to 10$)$ increased from $3.68 \pm 0.55 \mathrm{~m}^{2}$ at $\mathrm{LAI}=1.4$ to $15.57 \pm 3.26 \mathrm{~m}^{2}$ at $\mathrm{LAI}=6.7$. Short seedlings of the predominant weeds, Spanish needle (Bidens pilosa), purple nutsedge (Cyperus rotundus), and several grasses grew in the interrows.

Coffee phenology in the leeward environment of Kauai is characterized by seasonality with most vegetative growth from March to November (unpublished data). Flower induction and flower bud development begin in September and October, coincident with shortening daylength, and then the flower buds undergo a dormant period extending through the dry season. Dormancy is released by the first rains (Alvim, 1960; Crisosto et al., 1992). Subsequent anthesis and fruit development start around March (unpublished data).

Environmental conditions in each field during the measurement periods (Table 1) were recorded by sensors installed on a 7-m 
Table 1. Environmental conditions during the measurement periods at McBryde Sugar Co., Kauai Island.

\begin{tabular}{|c|c|c|c|c|c|c|c|c|c|}
\hline \multirow[b]{2}{*}{ Dates } & \multicolumn{2}{|c|}{$\begin{array}{l}\text { Net radiation } \\
\left(\mathrm{W} \cdot \mathrm{m}^{-2}\right)\end{array}$} & \multicolumn{3}{|c|}{$\begin{array}{l}\text { Air temp } \\
\text { (C) }\end{array}$} & \multicolumn{3}{|c|}{$\begin{array}{c}\text { Relative humidity } \\
(\%)\end{array}$} & \multirow{2}{*}{$\begin{array}{l}\text { Wind speed } \\
\qquad\left(\mathrm{m} \cdot \mathrm{s}^{-1}\right)\end{array}$} \\
\hline & Max & Mean & Min & Max & Mean & Min & Max & Mean & \\
\hline \multicolumn{10}{|c|}{1991} \\
\hline 17-22 Aug. & 740 & 438 & 23 & 29 & 27 & 58 & 82 & 67 & 2.3 \\
\hline 1-8 Nov. & 616 & 337 & 21 & 28 & 27 & 57 & 82 & 67 & 1.4 \\
\hline 24-27 July & 748 & 409 & 23 & 28 & 26 & 62 & 94 & 74 & 1.8 \\
\hline $8-12$ Oct. & 640 & 351 & 22 & 29 & 27 & 65 & 89 & 74 & 1.2 \\
\hline 7-12 Aug. & 765 & 418 & 23 & 28 & 26 & 60 & 81 & 68 & 1.8 \\
\hline 21-27 Oct. & 657 & 340 & 22 & 27 & 26 & 63 & 85 & 73 & 1.8 \\
\hline 10-14 July & 769 & 392 & 22 & 25 & 24 & 79 & 88 & 80 & 1.8 \\
\hline \multicolumn{10}{|c|}{1992} \\
\hline 29 July-5 Aug. & 742 & 465 & 24 & 29 & 28 & 62 & 77 & 67 & 2.3 \\
\hline 22-28 June & 771 & 461 & 23 & 29 & 27 & 58 & 76 & 64 & 1.8 \\
\hline 25-31 Aug. & 742 & 399 & 23 & 29 & 27 & 59 & 78 & 68 & 2.1 \\
\hline
\end{tabular}

${ }^{\mathrm{z} M e a n}$ daily values.

instrument tower (see section on ET /ET measurements) erected within each field. Approximately $17^{\mathrm{c}}$ to $20 \mathrm{~mm}$ of irrigation water were applied to each field through drip-irrigation lines placed along the base of the stems in the plant hedgerows, from 36 to 48 $\mathrm{h}$ before each set of ET determinations. The soil under the hedgerows was kept at field capacity as determined by daily monitoring of a set of 10, 20-cm long tensiometers installed in each field. This ensured that water availability was adequate over the 4to 8-day period during which ET was measured in each field. In one field $(\mathrm{LAI}=6.7)$, ET c was monitored during a 25 -day soil drying-reirrigation cycle.

$E T_{c} / E T_{0}$ measurements. Crop evapotranspiration $\left(\mathrm{ET}_{\mathrm{c}}\right)$ was measured as evaporative heat flux using the Bowen ratio-energy balance technique (Tanner, 1960). A movable 7-m instrument tower was positioned in each field to provide an upwind fetch $>100$ times the crop height. The tower remained in each field for 7 to 10 days. With this method, the surface energy balance is expressed as:

$$
\mathrm{R}_{\mathrm{n}}+\mathrm{G}+\mathrm{H}+\lambda \mathrm{E}=0
$$

Where $R_{n}$ is net radiation, $G$ is soil heat flux at the surface, $H$ is sensible heat flux, and $\lambda \mathrm{E}$ is latent (evaporative) heat flux. Net radiation was measured with a Fritschen net radiometer (model Q-6; Radiation Energy Balance Systems, Seattle) mounted $6.75 \mathrm{~m}$ above the soil surface. A second net radiometer was added during the second year so that each sensor was positioned directly above either the plant hedgerow or the interrow. Soil heat flux at the surface was measured using the combination method (Kimball and Jackson, 1979). One soil heat flux plate (model HFT-2; Radiation Energy Balance Systems, Seattle) and two soil thermocouples placed 1 and $2 \mathrm{~cm}$ below the soil surface were positioned at the edge of the hedgerow and a second soil heat flux plate and thermocouples were positioned in the middle of the interrow.

The Bowen ratio $(\beta)$, the ratio of sensible to latent heat flux from the canopy, was estimated as:

$$
\beta=\mathrm{H} / \lambda \mathrm{E}=\gamma \Delta \mathrm{T} / \Delta \mathrm{e}
$$

Where $\gamma$ is the psychrometric constant and $\Delta \mathrm{T}$ and $\Delta \mathrm{e}$ are gradients of temperature and vapor pressure measured over a fixed distance in the canopy boundary layer. Combining [Eqs. 1 and 2] gives an estimate of $\lambda \mathrm{E}$ as:

$$
\lambda \mathrm{E}=\left(\mathrm{R}_{\mathrm{n}}-\mathrm{G}\right) /(1+\beta)
$$

The gradients of temperature and water vapor were measured with a pair of chromel-constantan thermocouples mounted 5.25 and $6.50 \mathrm{~m}$ above the ground using a commercially available Bowen ratio system (Campbell Scientific, Logan, Utah). Air samples were taken at the same heights and passed through a dew point hygrometer (model Dew-10; General Eastern Corporation, Watertown, Mass.), which automatically switched positions every 5 min in response to a signal from a datalogger (model CR21X; Campbell Scientific). Crop evapotranspiration (ET $)$ was calculated from data averaged every $20 \mathrm{~min}$.

Weather data from an automated weather station (Campbell Scientific), within $1 \mathrm{~km}$ of the experimental fields at McBryde Sugar Co., were used to compute daily values of reference evapotranspiration $\left(\mathrm{ET}_{0}\right)$ from a modified Penman combination equation (Doorenbos and Pruitt, 1975).

Transpiration measurements. The stem heat balance (SHB) technique (Cermák et al., 1973; Vieweg and Ziegler, 1960) as modified by Sakuratani (1981) and Baker and Van Bavel (1987) was used to estimate the transpiration rate of the coffee plants. A detailed description of the operation theory of the SHB technique has been provided elsewhere (Baker and Van Bavel, 1987; Ham and Heilman, 1990; Sakuratani, 1981). In each field, eight commercially available stem sap flow gauges (models SGB13 to SGB25; Dynamax, Houston) were installed on major branches containing 1.5 to $5.5 \mathrm{~m}^{2}$ of leaf area distal to the gauge. The satisfactory performance of these gauges on coffee plants was verified by greenhouse experiments comparing SHB estimates of transpiration against weight loss of container-grown plants, and in field tests in which gauges were operated without power to their heaters to verify that externally induced stem temperature gradients were negligible (Gutiérrez et al., 1994). The sap flow gauges were operated under the control of a datalogger (model CR21X; Campbell Scientific) equipped with a 32-channel multiplexer (model AM416; Campbell Scientific). Data were recorded at 15-sec intervals and 20-min averages stored in a solid state storage module (model SM196; Campbell Scientific). At the end of each measurement period, branch leaf area was determined by complete defoliation and subsequent measurement in a leaf area meter (model 3100; LI-COR, Lincoln, Neb.). Rates of water flow through 
the coffee stems were normalized by dividing by the leaf area distal to the gauge to obtain transpiration rate on a unit leaf area basis. The resulting estimate of crop transpiration was scaled to a unit ground area basis by multiplying by the corresponding value of LAI of the whole canopy (Ham et al., 1990).

Additional measurements. For determination of LAI, eight to ten representative plants in each field were defoliated at the end of the measurement period in each field, and their total leaf area was determined in an area meter (model 3100; LI-COR). Average leaf area per plant was multiplied by the plant density to obtain a LAI value for each field.

Predawn and midday leaf water potentials $\left(\psi_{\mathrm{L}}\right)$ were determined with a pressure chamber in a field with a LAI $=6.7$ during a 25-day soil drying-reirrigation cycle. Branch tips containing one or two pairs of fully expanded leaves were enclosed in plastic bags before excision and kept in sealed bags in darkness after excision until measurement.

Diurnal courses of stomatal conductance $\left(g_{s}\right)$ were measured during 1 to 3 days in several fields with a portable photosynthesis system (model 6200; LI-COR) on sun and shade leaves in the upper and middle canopy layers.

Leaf temperature was determined with a set of $18 \mathrm{Cu}$-constantan thermocouples attached to the lower surface of the leaves and distributed throughout the canopy.

\section{Results and Discussion}

$E T_{c} / E T_{0}$ measurements. Average Kc ranged from 0.68 to 0.82 for 2- to 4-year-old crops in 1991 (Table 2). Average Kc for the 1.5-year-old field (LAI = 1.4) was 0.55. In 1992, Kc was about 0.45 for 2- to 3-year-old crops and 0.67 for the 5-year-old field. Values of Kc obtained in 1991 are consistent with those reported for coffee grown in other regions (Blore, 1966; Pereira, 1957; Wallis, 1963).

In 1991, Kc was significantly lower $(p<0.05)$ during September and November than during July and August, suggesting that a seasonal reduction in water use by coffee may have occurred independent of seasonal variation in evaporative demand. Seasonal fluctuations in stomatal activity, previously reported for coffee (Meinzer et al., 1992), may have played a role in reducing water use. These results suggest that irrigation requirements were lower during the late part of the dry season (October to December).

Crop coefficient values were substantially lower in 1992 than in 1991 at all ages sampled (Table 2). Several factors seemed to have played a role in reducing $\mathrm{Kc}$ in 1992 . Net radiation, a major determinant of $\mathrm{ET}_{0}$, was higher in 1992 (Table 1), and this was reflected in higher $\mathrm{ET}_{0}$ values in 1992. Lower relative humidity and higher wind speed recorded during 1992 (Table 1) may also have contributed to the observed reductions in ET (Table 2) by reducing stomatal conductance. Coffee stomata have previously been reported to exhibit a strong closing response to reduced atmospheric humidity (Fanjul et al., 1985). Average stomatal conductance $\left(\mathrm{g}_{\mathrm{s}}\right)$ was $0.10,0.11,0.12$, and $0.07 \mathrm{~mol} \cdot \mathrm{m}^{-2} \cdot \mathrm{s}^{-1}$ in fields with $\mathrm{LAI}=6.7,5.3,5.4$, and 1.4, respectively, in 1991, whereas in 1992 average $\mathrm{g}_{\mathrm{s}}$ was $0.08,0.11$, and $0.05 \mathrm{~mol} \mathrm{~m}^{-2} \mathrm{~s}^{-1}$ in fields with $\mathrm{LAI}=7.5,4.2$, and 3.4 (Table 2). Higher Bowen ratios were also recorded in 1992 (0.60 to 0.92) than in 1991 (0.45 to 0.66), indicating that a larger proportion of net radiation was consumed as sensible heat in 1992, although the irrigation regimes were similar both years.

The increase in $\mathrm{ET}_{\mathrm{c}}$ with LAI during each season reflected the activity of a larger evaporating surface as the canopy developed. Changes in the $\lambda E / R_{n}$ ratio as a function of LAI appeared to follow a sigmoidal pattern, increasing from 0.4 at $\mathrm{LAI}=1.4$ to values close to 0.6 at high LAI (data not shown). At LAI =6.7, the canopy shaded the soil during most of the day, suggesting that the remaining net radiation was consumed mainly as sensible heat, and that further increments in $\mathrm{ET}_{\mathrm{c}}$ with increasing LAI may have been small.

Transpiration. The transpiration component (T) of ET, expressed as the ratio $\mathrm{T}_{\mathrm{ET}}$ at different values of LAI (Fig. 1), followed a pattern consistent with previous observations on several annual crops (Al-Kaisi et al., 1989; Brun et al., 1972; Ritchie and Burnett, 1971). These reports mention the existence of a threshold LAI at which T equals ET. Threshold LAI has been found to be nearly 4 for soybean and sorghum (Brun et al., 1972), 2.7 for sorghum and cotton (Ritchie and Burnett, 1971), and from 3 to 3.7 for maize (Al-Kaisi et al., 1989). For coffee fields grown under wide row spacing in a hedgerow configuration, $T$ comprised $30 \%$ to $40 \%$ of ET at low LAI values, and then increased steadily to $95 \%$ at $\mathrm{LAI}=6.7$ (Fig. 1 ).

Diurnal patterns of T and ET for different LAI values (Fig. 2) confirmed that at low LAI (1.4 and 3.4) T comprised a small fraction of ET (see also Table 2), while at high LAI (6.7), T tended to equal $\mathrm{ET}_{\mathrm{c}}$ except during midday hours, when soil evaporation

Table 2. Average $( \pm \mathrm{SE})$ stomatal conductance $\left(\mathrm{g}_{\mathrm{S}}\right)$, transpiration $(\mathrm{T})$, crop $\left(\mathrm{ET}_{\mathrm{C}}\right)$ and reference $(\mathrm{ETo})$ evapotranspiration, and Kc of coffee fields in Hawaii.

\begin{tabular}{|c|c|c|c|c|c|c|c|}
\hline $\begin{array}{l}\text { Age } \\
\text { (yrs) }\end{array}$ & LAI & Dates & $\begin{array}{c}\mathrm{g}_{\mathrm{s}} \\
\left(\mathrm{mol} \cdot \mathrm{m}^{-2} \cdot \mathrm{s}^{-1}\right)\end{array}$ & $\begin{array}{c}\mathrm{T} \\
\left(\mathrm{mm} \cdot \mathrm{day}^{-1}\right)\end{array}$ & $\begin{array}{c}\mathrm{ET}_{\mathrm{C}} \\
\left(\mathrm{mm} \cdot \mathrm{day}^{-1}\right)\end{array}$ & $\begin{array}{c}\mathrm{ET}_{\mathrm{O}} \\
\left(\mathrm{mm} \cdot \mathrm{day}^{-1}\right)\end{array}$ & $\mathrm{Kc}$ \\
\hline \multicolumn{8}{|c|}{1991} \\
\hline \multirow[t]{2}{*}{1.5} & 1.4 & 17-22 Aug. & N.A. ${ }^{z}$ & $0.97 \pm 0.12$ & $4.01 \pm 0.54$ & $6.79 \pm 0.24$ & $0.59 \pm 0.06$ \\
\hline & & 1-8 Nov. & $0.07 \pm 0.01$ & $0.67 \pm 0.12$ & $2.04 \pm 0.20$ & $4.06 \pm 0.41$ & $0.51 \pm 0.08$ \\
\hline \multirow[t]{2}{*}{2.4} & 5.4 & 7-12 Aug. & N.A. & $3.30 \pm 0.48$ & $5.31 \pm 0.45$ & $6.52 \pm 0.52$ & $0.82 \pm 0.04$ \\
\hline & & 21-27 Oct. & $0.12 \pm 0.02$ & $2.95 \pm 0.31$ & $3.40 \pm 0.32$ & $4.40 \pm 0.61$ & $0.78 \pm 0.06$ \\
\hline \multirow[t]{2}{*}{3.0} & 5.3 & 24-27 July & N.A. & $3.58 \pm 0.40$ & $5.31 \pm 0.39$ & $6.22 \pm 0.17$ & $0.81 \pm 0.04$ \\
\hline & & $8-12$ Oct. & $0.11 \pm 0.03$ & $2.37 \pm 0.18$ & $3.40 \pm 0.20$ & $4.64 \pm 0.32$ & $0.68 \pm 0.02$ \\
\hline \multirow[t]{3}{*}{4.3} & 6.7 & 10-14 July & N.A. & N.A. & $5.23 \pm 0.10$ & $6.60 \pm 0.10$ & $0.79 \pm 0.04$ \\
\hline & & 1-05 Sept. & $0.10 \pm 0.03$ & $3.63 \pm 0.35$ & $3.70 \pm 0.56$ & $4.99 \pm 0.70$ & $0.74 \pm 0.01$ \\
\hline & & & & 92 & & & \\
\hline 2.0 & 3.4 & 29 July-5 Aug. & $0.05 \pm 0.01$ & $1.49 \pm 0.25$ & $3.58 \pm 0.17$ & $7.40 \pm 0.27$ & $0.48 \pm 0.02$ \\
\hline 3.1 & 4.2 & 22-28 June & $0.11 \pm 0.03$ & N.A. & $3.13 \pm 0.47$ & $7.42 \pm 0.49$ & $0.42 \pm 0.06$ \\
\hline 5.3 & 7.5 & 25-31 Aug. & $0.08 \pm 0.02$ & N.A. & $3.88 \pm 0.34$ & $5.92 \pm 0.82$ & $0.67 \pm 0.12$ \\
\hline
\end{tabular}

${ }^{\mathrm{z}}$ Data not available. 


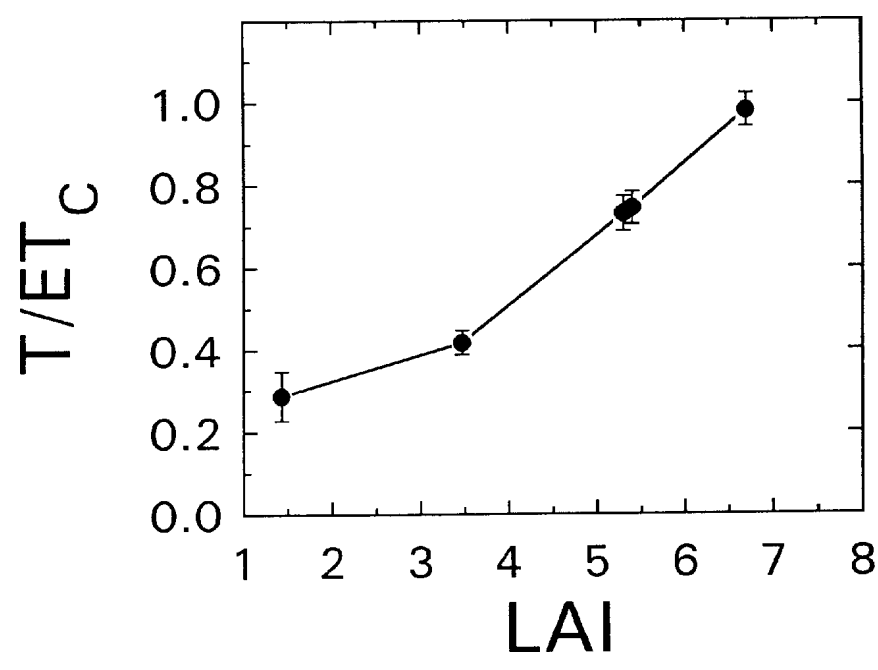

Fig. 1. The relationship between crop transpiration expressed as a fraction of crop evapotranspiration $\left(\mathrm{T} / \mathrm{ET}_{\mathrm{c}}\right.$ ) and canopy development (leaf area index) in coffee fields.

presumably became more important as a result of increasing irradiance in the interrows. Coffee transpiration rate measured with the SHB technique closely agreed with average values of 0.8 to $0.9 \mathrm{mmol} \cdot \mathrm{m}^{-2} \cdot \mathrm{s}^{-1}$ previously determined by Nutman (1941) using a lysimeter. Substantial evaporation of dew from the canopy surface seemed to have occurred on 30 Aug. 1991, as judged by the high ET recorded in the absence of $\mathrm{T}$ during the early morning hours (Fig. 2).
These diurnal courses revealed that in fields with low LAI values (1.4 and 3.4) ET was higher between 1400 and $1600 \mathrm{~h}$ than earlier in the day (Fig. 2). This contrasts with $\mathrm{T}$, which peaked during the morning and early afternoon hours in fields with low LAI. At LAI = 6.7, both ET and T reached maximum rates around midday and decreased steadily during the afternoon. The behavior of ET in fields with low LAI did not appear to be associated with $\mathrm{R}_{\mathrm{n}}$, which began to decrease at $\approx 1400 \mathrm{~h}$ (Fig. 2). Soil temperature, on the other hand, attained its maximum values at about $1400 \mathrm{~h}$ in fields with low LAI and may have caused ET to remain high during the latter part of the day (Fig. 2). In fields with high LAI (6.7, Fig. 2) where T/ET was close to 1, soil temperature was lower and decreased rapidly after midday. Fields with low LAI thus reduced interception of radiation by the coffee canopy and increased the amount of radiation available for heating of the soil surface.

Patterns of leaf temperature in relation to soil temperature also suggested that soil heating played an important role as a driving force for evapotranspiration in fields with low LAI by increasing soil water evaporation and/or understory transpiration. In the field with the lowest LAI (1.4, Fig. 2), leaf temperature was at least 4C lower than soil temperature during the afternoon hours. In fields with higher LAI, the daily course of leaf temperature closely paralleled that of soil temperature, particularly in the afternoon hours. The behavior of soil and leaf temperature and of ET and T in relation to LAI suggests that it may be possible to reduce water consumption in coffee fields with low LAI by removing the vegetation growing in the interrows or by the use of organic or plastic mulches. However, such practices may also increase soil surface temperature (e.g., in dry soil) and promote within-row

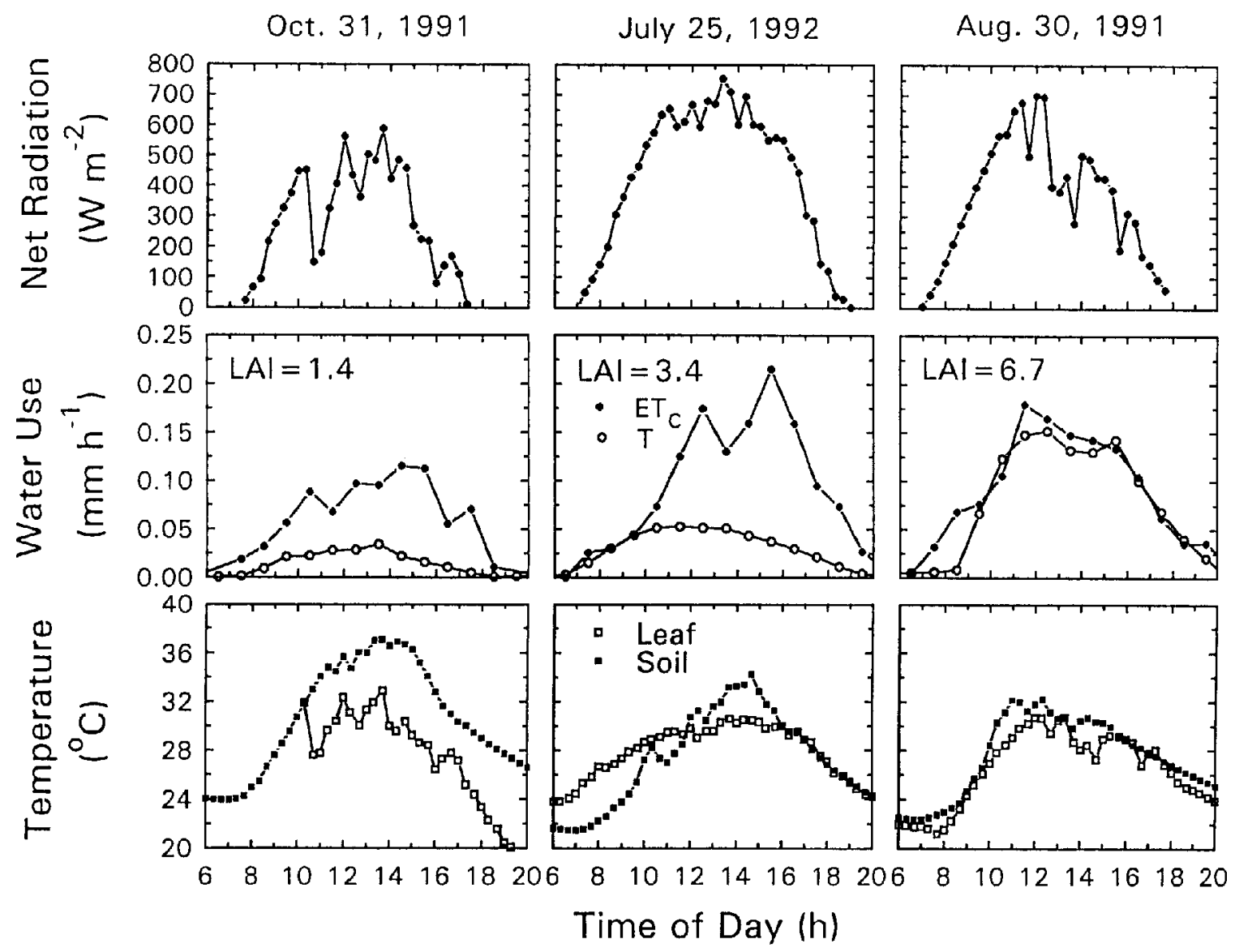

Fig. 2. Diurnal courses of net radiation, crop transpiration (T), and evapotranspiration (ET $)$ determined with the SHB and Bowen ratio techniques, respectively, and leaf and soil temperature at three different leaf area indexes. 


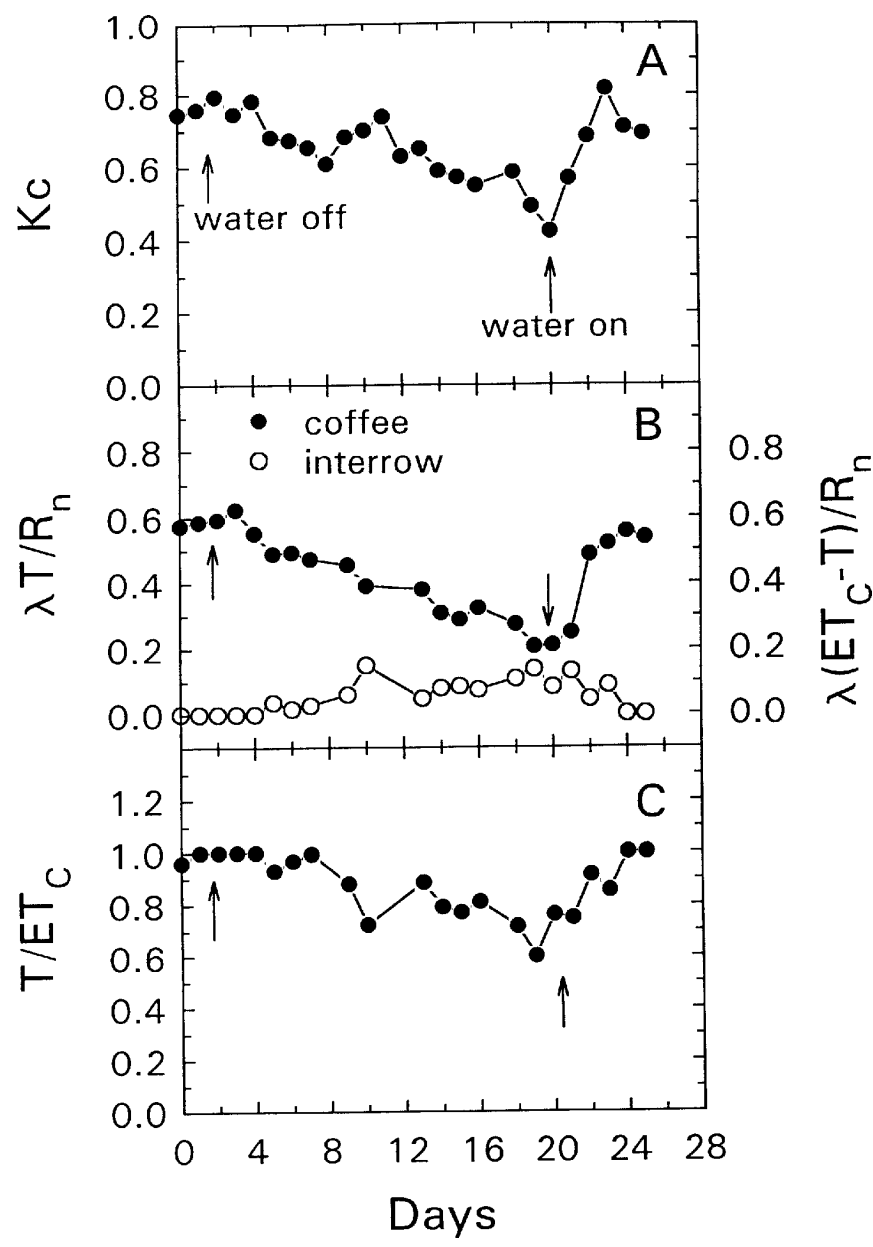

Fig. 3. Changes in the crop coefficient $(\mathrm{Kc})(\mathbf{A})$, crop and interrow latent heat flux to net radiation ratio $(\mathbf{B})$, and crop transpiration to crop evapotranspiration ratio (C), in a 4-year-old coffee field (leaf area index $=6.7$ ) monitored during a soil drying-reirrigation cycle between 29 Aug. and 23 Sept. 1991.

advection, increasing crop transpiration and keeping the net flux of water from the field unchanged (Villalobos and Fereres, 1990).

Responses to water deficit. A 25-day soil drying-reirrigation cycle was imposed on a field with $\mathrm{LAI}=6.7$. Kc began to decline shortly after irrigation was suspended (Fig. 3A). After day-to-day variations in $\mathrm{T}$ and $\mathrm{ET}$ were normalized by dividing by the corresponding daily $\mathrm{R}_{\mathrm{n}}$, it became apparent that the initial decline in $\mathrm{Kc}$ was entirely attributable to reductions in $\mathrm{T}$ after irrigation was discontinued (Fig. 3B). After 8 days without irrigation, T/ET began to decline also, indicating that the soil and the interrow vegetation began contributing to $\mathrm{ET}_{c}$ (Fig. 3C). Examination of the components of $\mathrm{ET}_{\mathrm{c}}$ revealed that the decline in $\lambda \mathrm{T} / \mathrm{R}_{\mathrm{n}}$ (Fig. $3 \mathrm{~B}$ ) was continuous, but 8 days after withholding irrigation the interrows began contributing to ET . Leaf wilting presumably played a role in causing this response by increasing the ground area exposed to direct radiation.

Transpiration (normalized for variations in $\mathrm{R}_{\mathrm{n}}$ ) started to decline (Fig. 3B) before any reduction in $\psi_{\mathrm{L}}$ could be detected (Fig. 4). This indicated that stomatal restriction of transpiration was taking place in the absence of changes in the bulk leaf water status. Observations consistent with this behavior have been interpreted as cases of root-to-shoot communication (Bates and Hall, 1981; Crisosto et al., 1992; Davies and Zhang, 1991), in which root signals mediate stomatal responses to soil drying before changes in the water status of the shoot occur.

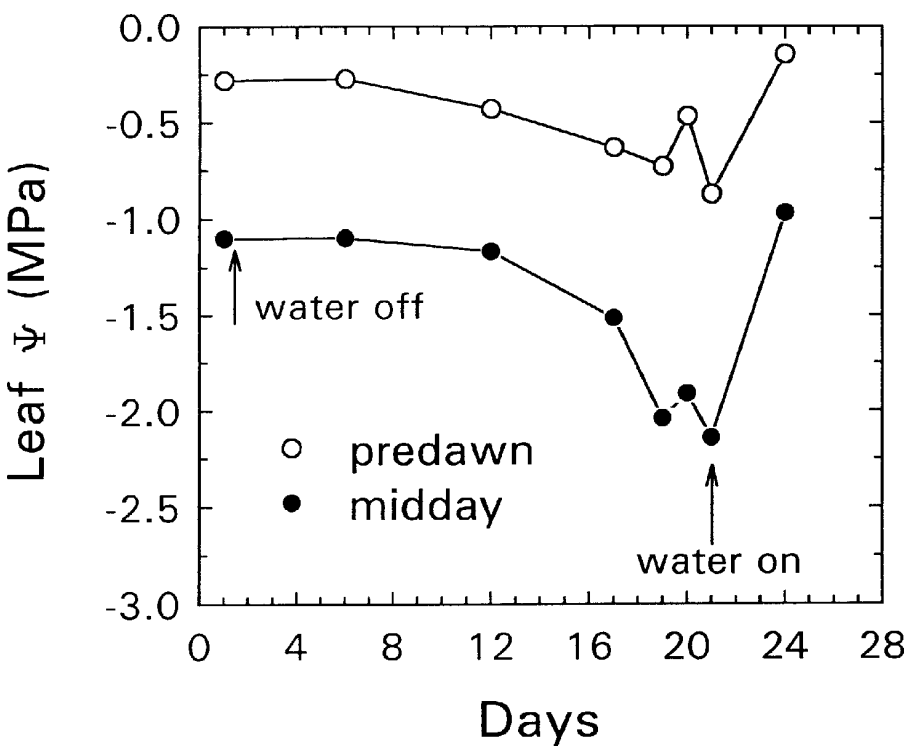

Fig. 4. Changes in predawn and midday leaf water potential $\left(\psi_{\mathrm{L}}\right)$ during a soil drying-reirrigation cycle in a field with a leaf area index $=6.7$, between 29 Aug. and 23 Sept. 1991.

Crop coefficient had dropped to about 0.4 when irrigation was resumed 18 days after the last irrigation. Although the leaves were visibly wilted by this time and $\psi_{\mathrm{L}}$ had reached $-2.14 \mathrm{MPa}$ at midday (Fig. 4), the Kc value of 0.4 and the value of $\mathrm{T}$ at $\approx 30 \%$ of its original value suggested that substantial gas exchange was still taking place. Stomatal conductance decreased from $0.10 \mathrm{~mol} \cdot \mathrm{m}^{-}$ ${ }^{2} \cdot \mathrm{s}^{-1}$ under well-irrigated conditions to $0.02 \mathrm{~mol} \cdot \mathrm{m}^{-2} \cdot \mathrm{s}^{-1} 23$ days after the drying cycle had been imposed. Upon reirrigation, $\psi_{\mathrm{L}}, \mathrm{T}$, and $\mathrm{Kc}$ rapidly returned to their original levels. These observations are consistent with previous reports that coffee is able to sustain relatively high levels of gas-exchange activity even under severe water deficit (Meinzer et al., 1990), and they attest to coffee's high degree of drought tolerance.

Conclusions. Given the important role played by water deficit in the control of flower opening in coffee (Alvim, 1960), the data obtained in the present study should prove useful in the formulation of models aimed at manipulating the water regime to control coffee flowering under field conditions (Crisosto et al., 1992). Our results indicate that $\mathrm{Kc}$ for coffee ranged from 0.7 to 0.8 at all except the lowest values of LAI examined, and that the crop maintains a substantial level of gas exchange even under severe water deficits. Crop transpiration became an increasingly important component of ET as the canopy developed, and soil temperature (i.e., within-row advection) played a predominant role in driving evapotranspiration at early stages of canopy development. Variations in stomatal behavior seemed to be responsible for seasonal and year-to-year differences in water use and Kc.

\section{Literature Cited}

Al-Kaisi, M., L.J. Brun, and J.W. Enz. 1989. Transpiration and evapotranspiration from maize as related to leaf area index. Agr. For. Meteorol. 48:111-116.

Alvim, P. de T. 1960. Moisture stress as a requirement for flowering of coffee. Science 132:354.

Baker, J.N. and C.H.M. Van Bavel. 1987. Measurement of mass flow of water in the stems of herbaceous plants. Plant, Cell \& Environ. 10:777782.

Bates, L.M. and A.E. Hall. 1981. Stomatal closure with soil water depletion not associated with changes in bulk leaf water status. Oecologia 50:62-65 
Blore, T.W.D. 1966. Further studies of water use by irrigated and unirrigated Arabica coffee in Kenya. J. Agr. Sci. Cambridge 67:145154.

Browning, G. and N.M. Fisher. 1975. Shoot growth in Coffea arabica L. II. Growth flushing stimulated by irrigation. J. Hort. Sci. 50:207-218.

Brun, L.J., E.T. Kanemasu, and W.L. Powers. 1972. Evapotranspiration from soybean and sorghum fields. Agron. J. 64:145-148.

Cannell, M.G.R. 1971. Production and distribution of dry matter in trees of Coffea arabica L. in Kenya as affected by seasonal climatic differences and the presence of fruits. Ann. Applied Biol. 67:99-120.

Cermák, J., J. Deml, and M. Penka. 1973. A new method of sap flow determination in trees. Biol. Plant. 15:171-178.

Crisosto, C.H., D.A. Grantz, and F.C. Meinzer. 1992. Effects of water deficits on flower opening in coffee (Coffea arabica L.). Tree Physiol. 10:127-139.

Davies, W.J. and J.Zhang. 1991. Root signals and the regulationof growth and development of plants in drying soil. Annu. Rev. Plant Physiol. Plant Mol. Biol. 42:55-76.

Doorenbos, J. and W.O. Pruitt. 1975. Crop water requirements. Food and Agricultural Organization, Rome. Irr. and Drainage Paper no. 24. 144 p.

Fanjul, L., R. Arreola-Rodr1guez, and M.P. M)ndez-Castej;n. 1985. Stomatal responses to environmental variables in shade and sun grown coffee plants in Mexico. Expt. Agr. 21:249-258.

Gutiérrez, M.V., R.A. Harrington, F.C. Meinzer, and J.H. Fownes. 1994. The effect of environmentally induced stem temperature gradients on transpiration estimates from the heat balance method in two tropical woody species. Tree Physiol. 14:179-190.

Ham, J.M. and J.L. Heilman. 1990. Dynamics of a heat balance stem flow gauge during high flow. Agron. J. 82:147-152.

Ham, J.M., J.L. Heilman, and R.J. Lascano. 1990. Determination of soilwater evaporation and transpiration from energy balance and stem flow measurements. Agr. For. Meteorol. 52:287-301.

Kimball, B.A. and R.D. Jackson. 1979. Soil heat flux, p. 211-229. In: B.J. Barfield and J.F. Gerber (eds.). Modification of the aerial environment of plants. Amer. Soc. Agr. Eng. St. Joseph, Mich. Monogr. no. 2.

Meinzer, F.C., D.A. Grantz, G. Goldstein, and N.Z. Saliendra. 1990. Leaf water relations and maintenance of gas exchange in coffee cultivars grown in drying soil. Plant Physiol. 94:1781-1787.

Meinzer, F.C., N.Z. Saliendra, and C.H. Crisosto. 1992. Carbon isotope discrimination and gas exchange in Coffea arabica during adjustment to different soil moisture regimes. Austral. J. Plant Physiol. 19:171-184.

Nutman, F.J. 1941. Studies of the physiology of Coffea arabica. III. Transpiration rates of whole trees in relation to natural environmental conditions. Ann. Bot. 5:59-81.

Pereira, H.C. 1957. Field measurements of water use for irrigation control in Kenya coffee. J. Agr. Res. 49:459-466.

Ritchie, J.T. and E. Burnett. 1971. Dryland evaporative flux in a subhumid climate: II. Plant influences. Agron. J. 63:56-62.

Sakuratani, T. 1981. A heat balance method for measuring water flux in the stems of intact plants. J. Agr. Meteorol. 37:9-17.

Tanner, C.B. 1960. Energy balance approach to evapotranspiration from crops. Soil Sci. Soc. Amer. Proc. 24:1-9.

United States Department of Agriculture. 1991. Hawaii Coffee. Sept. 1991. U.S. Dept. of Agr., Hawaii Agricultural Statistics Service, Honolulu.

Vieweg, G.H. and H. Ziegler. 1960. Thermoelektrische registrerium der geschwindigkeit des transpirationstromes. Berichte Deutsche Botanische Gesellschaft 73:221-226.

Villalobos, F.J. and E. Fereres. 1990. Evaporation measurements beneath corn, cotton, and sunflower canopies. Agron. J. 82:1153-1159.

Wallis, J.A.N. 1963. Water use by irrigated Arabica coffee in Kenya. J. Agr. Sci. 60:381-388. 